\title{
Front Matter: Volume 10626
}

, "Front Matter: Volume 10626," Proc. SPIE 10626, Tri-Technology Device Refrigeration (TTDR) III, 1062601 (30 May 2018); doi: 10.1117/12.2322384

SPIE. Event: SPIE Defense + Security, 2018, Orlando, FL, United States 


\title{
PROCEEDINGS OF SPIE
}

\section{Tri-Technology Device Refrigeration (TTDR) III}

\author{
Mansoor Sheik-Bahae \\ Richard I. Epstein \\ Bjørn F. Andresen \\ Tonny Benschop \\ Joseph P. Heremans \\ Sergey V. Riabzev \\ Editors
}

18 April 2018

Orlando, Florida, United States

Sponsored and Published by

SPIE 
The papers in this volume were part of the technical conference cited on the cover and title page. Papers were selected and subject to review by the editors and conference program committee. Some conference presentations may not be available for publication. Additional papers and presentation recordings may be available online in the SPIE Digital Library at SPIEDigitalLibrary.org.

The papers reflect the work and thoughts of the authors and are published herein as submitted. The publisher is not responsible for the validity of the information or for any outcomes resulting from reliance thereon.

Please use the following format to cite material from these proceedings:

Author(s), "Title of Paper," in Tri-Technology Device Refrigeration (TTDR) III, edited by Mansoor SheikBahae, Richard I. Epstein, Bjørn F. Andresen, Tonny Benschop, Joseph P. Heremans, Sergey V.

Riabzev, Proceedings of SPIE Vol. 10626 (SPIE, Bellingham, WA, 2018) Seven-digit Article CID Number.

ISSN: 0277-786X

ISSN: 1996-756X (electronic)

ISBN: 9781510617636

ISBN: 9781510617643 (electronic)

Published by

SPIE

P.O. Box 10, Bellingham, Washington 98227-0010 USA

Telephone +1 3606763290 (Pacific Time) · Fax +1 3606471445

SPIE.org

Copyright (C) 2018, Society of Photo-Optical Instrumentation Engineers.

Copying of material in this book for internal or personal use, or for the internal or personal use of specific clients, beyond the fair use provisions granted by the U.S. Copyright Law is authorized by SPIE subject to payment of copying fees. The Transactional Reporting Service base fee for this volume is $\$ 18.00$ per article (or portion thereof), which should be paid directly to the Copyright Clearance Center (CCC), 222 Rosewood Drive, Danvers, MA 01923. Payment may also be made electronically through CCC Online at copyright.com. Other copying for republication, resale, advertising or promotion, or any form of systematic or multiple reproduction of any material in this book is prohibited except with permission in writing from the publisher. The CCC fee code is 0277$786 \mathrm{X} / 18 / \$ 18.00$.

Printed in the United States of America.

Publication of record for individual papers is online in the SPIE Digital Library.

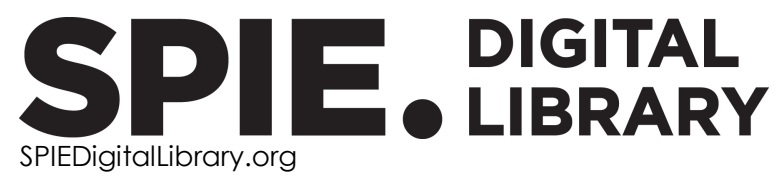

Paper Numbering: Proceedings of SPIE follow an e-First publication model. A unique citation identifier (CID) number is assigned to each article at the time of publication. Utilization of CIDs allows articles to be fully citable as soon as they are published online, and connects the same identifier to all online and print versions of the publication. SPIE uses a seven-digit CID article numbering system structured as follows:

- The first five digits correspond to the SPIE volume number.

- The last two digits indicate publication order within the volume using a Base 36 numbering system employing both numerals and letters. These two-number sets start with 00, 01, 02, 03, 04, 05, 06, 07, 08, 09, OA, OB ... 0Z, followed by 10-1Z, 20-2Z, etc. The CID Number appears on each page of the manuscript. 


\title{
Contents
}

\author{
$\checkmark \quad$ Authors \\ vii Conference Committee
}

SESSION 1 MECHANICAL COOLERS: MINIATURIZATION

1062602 Performance of the Lockheed Martin Space MINI cryocooler [10626-1]

1062603 Experimental investigation on the miniature mixed refrigerant cooler driven by a minicompressor [10626-2]

1062604 Computational fluid dynamics study of displacer "shuttle loss" in miniature Stirling cryocoolers [10626-3]

1062605 RMs1: the state of the art SWaP cryocooler [10626-4]

SESSION 2 MECHANICAL COOLERS: DESIGN AND TESTING I

1062608 Ruggedizing vibration sensitive components of electro-optical module using wideband dynamic absorber [10626-7]

1062609 A 50W@170K pulse tube cryocooler used in wide-field survey telescope [10626-8]

10626 OA MEMS based shock pulse detection sensor for improved rotary Stirling cooler end of life prediction [10626-9]

SESSION $3 \quad$ LASER CRYOCOOLERS

10626 OB Realization of an all-solid-state cryocooler using optical refrigeration (Invited Paper) [10626-10]

SESSION 4 MECHANICAL COOLERS: DESIGN AND TESTING II

10626 OE Robust Stirling coolers for sensing in extreme environmental conditions [10626-13]

10626 OF Structural analysis of an infrared focal plane dewar assembly for meteorological satellite [10626-14]

10626 OG Overview of RICOR's reliability theoretical analysis, accelerated life demonstration test results and verification by field data [10626-15]

$10626 \mathrm{OH} \quad$ Lifetime validation of high-reliability $(>30,000 \mathrm{hr})$ rotary cryocoolers for specific customer profiles [10626-16]

10626 OK Northrop Grumman HEC flight coaxial cryocoolers performance [10626-19] 
Proc. of SPIE Vol. 10626 1062601-4 Downloaded From: https://www.spiedigitallibrary.org/conference-proceedings-of-spie on 25 Apr 2023
Terms of Use: https://www.spiedigitallibrary.org/terms-of-use 


\section{Authors}

Numbers in the index correspond to the last two digits of the seven-digit citation identifier (CID) article numbering system used in Proceedings of SPIE. The first five digits reflect the volume number. Base 36 numbering is employed for the last two digits and indicates the order of articles within the volume. Numbers start with 00, 01, 02, 03, 04, 05, 06, 07, 08, 09, 0A, 0B...0Z, followed by 10-1Z, 20-2Z, etc.

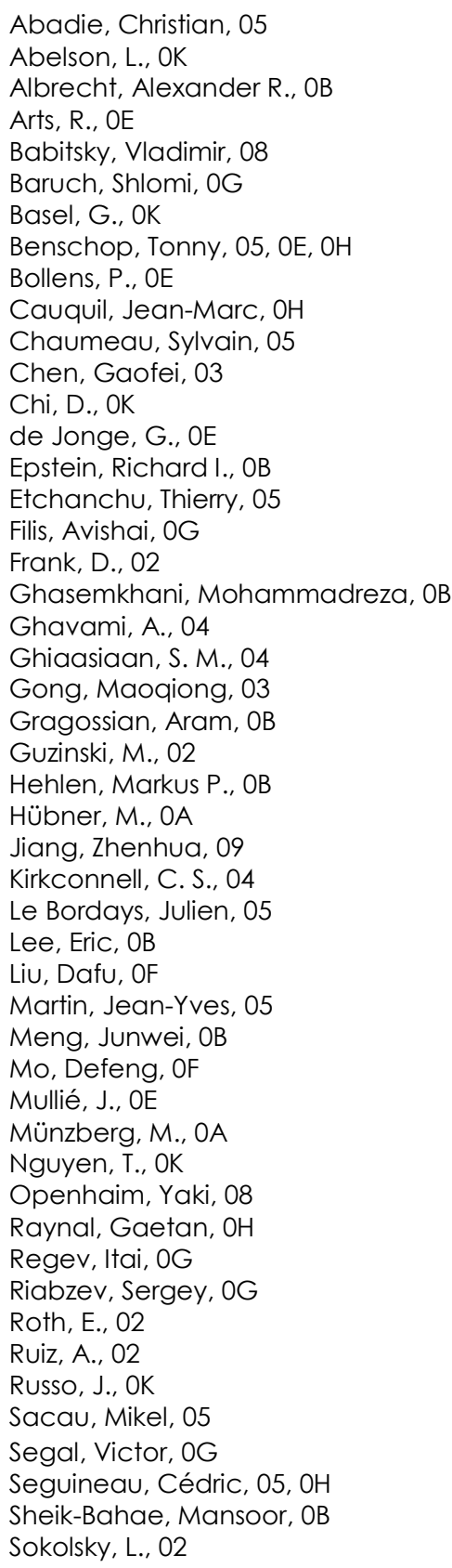

\author{
Sun, Wen, OF \\ Tuito, Avi, 08 \\ Vainshtein, Igor, OG \\ Van-Acker, Sébastien, 05 \\ van Leeuwen, R., OE \\ Vasse, Christophe, $05, \mathrm{OH}$ \\ Veprik, Alexander, 08 \\ Volpi, Azzurra, OB \\ Willems, D., OE \\ Wu, Yinong, 03, 09 \\ $\mathrm{XU}, \mathrm{Lin}, \mathrm{OF}$ \\ Xu, Qinfei, OF \\ Zhang, Lei, OF
}


Proc. of SPIE Vol. 10626 1062601-6

Downloaded From: https://www.spiedigitallibrary.org/conference-proceedings-of-spie on 25 Apr 2023 Terms of Use: https://www.spiedigitallibrary.org/terms-of-use 


\title{
Conference Committee
}

\author{
Symposium Chair
}

Arthur A. Morrish, Raytheon Space and Airborne Systems

(United States)

Symposium Co-chair

Ruth Moser, Air Force Research Laboratory (United States)

Conference Chairs

Richard I. Epstein, The University of New Mexico (United States) and ThermoDynamic Films, LLC (United States)

Bjørn F. Andresen, Consultant, Infrared Technologies \& Applications (Israel)

Tonny Benschop, Thales Cryogenics B.V. (Netherlands)

Joseph P. Heremans, The Ohio State University (United States)

Sergey V. Riabzev, RICOR Cryogenic \& Vacuum Systems (Israel)

Mansoor Sheik-Bahae, The University of New Mexico (United States)

Conference Program Committee

Igor D. Burlakov, Orion Research-and-Production Association (Russian Federation)

Bernardo Farfan, The University of New Mexico (United States) and ThermoDynamis Films, LLC (United States)

Matthew Grayson, Northwestern University (United States)

Markus P. Hehlen, Los Alamos National Laboratory (United States)

Carl S. Kirkconnell, West Coast Solutions (United States)

Ingo N. Rühlich, AIM INFRAROT-MODULE GmbH (Germany)

Alexander Veprik, SCD SemiConductor Devices (Israel)

Yinong Wu, Shanghai Institute of Technical Physics (China)

Session Chairs

1 Mechanical Coolers: Miniaturization

Carl S. Kirkconnell, West Coast Solutions (United States)

Ingo N. Rühlich, AIM INFRAROT-MODULE GmbH (Germany) 
2 Mechanical Coolers: Design and Testing I

Sergey V. Riabzev, RICOR Cryogenic \& Vacuum Systems (Israel)

Yinong Wu, Shanghai Institute of Technical Physics (China)

3 Laser Cryocoolers

Mansoor Sheik-Bahae, The University of New Mexico (United States)

Jun Zhang, Institute of Semiconductors (China)

4 Mechanical Coolers: Design and Testing II

Tonny Benschop, Thales Cryogenics B.V. (Netherlands)

Alexander Veprik, SCD SemiConductor Devices (Israel) 